\title{
REVISÃO DE MODELAGEM DE MISTURAS DE CARVÃO PARA PREDIÇÃO DE QUALIDADE DO COQUE*
}

\author{
Mariano de Córdova ${ }^{1}$ \\ Jorge Madias ${ }^{2}$ \\ Javier Barreiro ${ }^{3}$
}

\section{Resumo}

A operação dos altos-fornos com injeção de carvão pulverizado ou gás natural requer uma alta qualidade do coque. Para um custo mínimo do coque, mantendo a qualidade necessária, a escolha de carvões e a formulação da mistura é um tema muito importante. Uma ferramenta amplamente utilizada para o design de misturas é a modelagem, precedido pela caracterização de carvões e seguido de teste no forno piloto. Neste trabalho, revisa-se o desenvolvimento dos modelos, com base la literatura pública. Três etapas cronológicas são levadas em conta, desde os anos sessenta até a atualidade.

Palavras-chave: Mistura de carvões; Caracterização de carvões; Caracterização do coque; Modelagem de misturas.

\section{REVIEW OF MODELING OF COAL BLENDS FOR PREDICTION OF COKE Abstract}

The operation of blast furnaces with coal/natural gas injection requires high coke quality. For lowest coke cost while keeping the necessary coke quality, the choice of coals and the formulation of the blend is a very important issue. A widely utilized tool for blend design is modeling, preceded by coal characterization and followed by pilot oven testing. In this paper, the development of models is reviewed, based on public literature. Three main stages are taken into account, form the sixties to current times. Keywords: Coal blend; Coal characterization; Coke characterization; Coal blen modeling.

\footnotetext{
Mechanical Engineer, Consultant, metallon, San Nicolas, Buenos Aires, Argentina.

Metalurgical Engineer, Director, metallon, San Nicolas, Buenos Aires, Argentina.

Electronic Engineer, Engineering Manager, ANT Automation LLC, Pittsburgh, Pennsylvania, USA.
} 


\section{INTRODUCTION}

The operation of blast furnaces with coal/natural gas injection requires high coke quality. For lowest coke cost while keeping the necessary coke quality, the choice of coals and the formulation of the blend is a very important issue. A widely utilized tool for blend design is modeling, preceded by coal characterization and followed by pilot oven testing. In this paper, the development of models is reviewed, based on public literature. Three main stages are taken into account, form the sixties to current times.

\section{FIRST STAGE}

\subsection{Earlier times}

Till mid-sixties, the seaborne coal trade was small, mostly form North America to Europe and Asia. At the same time, most of the coking coal consumed in Europe and North America came from domestic mines. Even Japan used to have local sources [1]. In this frame, models developed were mostly local/regional, based on the features of local coals. We discuss briefly the models developed in North America, Germany, Australia and South Africa.

\subsection{North America}

The most important modeling effort was that of Shapiro and Gray [2-3] at US Steel. It was based on petrography to determine coke stability when using Appalachian coals (east of USA). The macerals were divided in active and inert. Active macerals taken into account include vitrinite, exinite and one third of semifusinite, while inert macerals were inertinite, mineral matter and two thirds of semifusinite. They made use of the reflectogram of total reactives, considered as vitrinite, classified in 21 groups (V1 to V21).

The Composition Balance Index $(\mathrm{CBI})$ is calculated as a function of the total of inerts and the sum of the optimal ratio between reactives and inerts $(R / I)$ given by each vitrinite type, according to an experimental curve. The Strength Index (SI) is defined as a function of total of reactives, total of inerts and the sum of the strength factors contributed by each vitrinite type, according to an experimental curve.

Using a graph with isostability curves, coke stability is defined taking into account the values of $\mathrm{CBI}$ and $\mathrm{SI}$ obtained (fig. 1).

The basic concept behind this model, relating coal petrography to coke quality, was to have a long lasting influence on coke quality prediction. Other models followed: The Illinois State Geological Survey proposed one for Illinois coals, under a similar frame, but changing the curves for calculation of $\mathrm{CBI}$ and SI [4]. A coal mining company, Consol, developed a model considered a synthesis of the two previous conceptions. It uses different curves to calculate an Inert Index (II), similar to CBI and SI [3]. Benedict at Bethlehem Steel, built a model for East Kentucky coals. He added seudovitrinite to the macerals considered by Shapiro and Gray. The prediction of coke stability is made in function of effective inerts and reflectivity of vitrinite [2-3].

Later on, in 1977, Kaegy from Inland Steel put together a calculation for coals from Illinois, Indiana, West Virginia, Alabama, Kentucky Pennsylvania and Maryland. He included seudovitrinite, macrinite, seudomacrinite and oxyvitrinite. The same curves developed by Consol are employed for the calculation of II and SI [3]. 
In the meantime, some Canadian studies proposed modifications to Shapiro -Gray model taking into account specific features of the domestic coals. Most coals of the West Canada coast have more semifusinite content than those in the Shapiro-Gray scheme, and calculated stability was lower than measured. Studies by Carr and Jorgensen concluded that quality prediction fitted if one half of semifusinite was considered reactive and the other half as inert, for coals with $20 \%$ or more of semifusinite [7-8]. Leeder and Price, from CANMET, gave an important step ahead including coal rheology in the prediction scheme [7]. Their graph was based on results of 180 coke oven tests, see figure 2 .

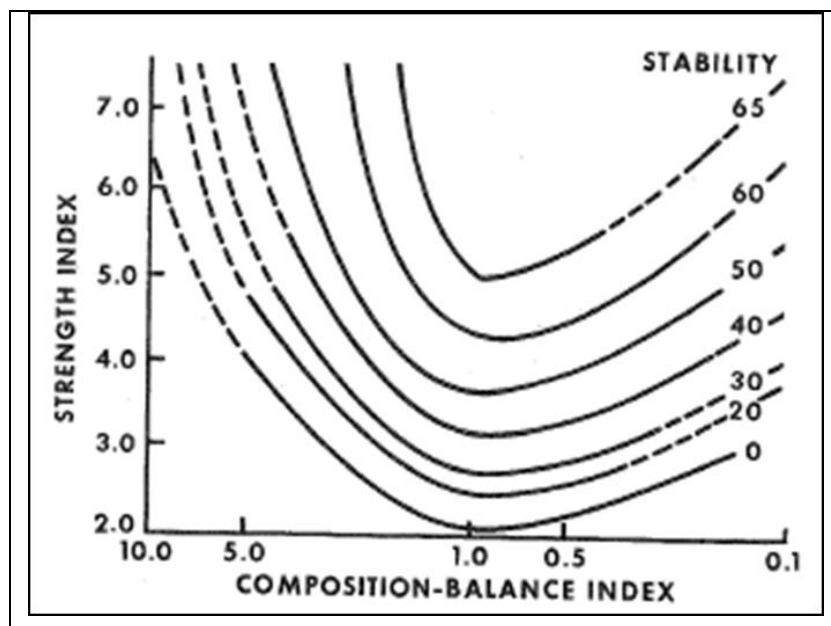

Fig. 1. Shapiro-Gray's US Steel model

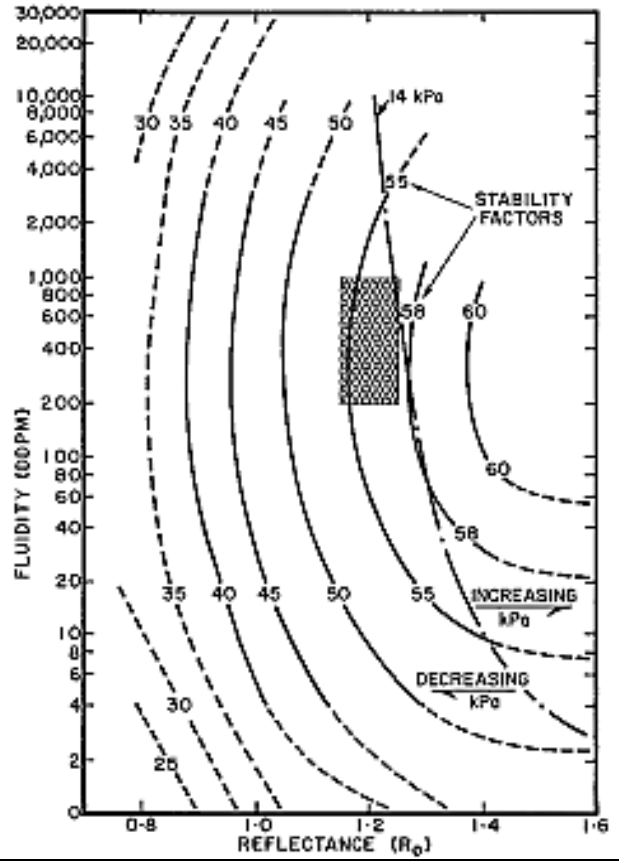

Fig. 2. Graph for prediction of coke stability based on coal reflectance and rheology, taken into account results of 180 tests in pilot coke oven, by CANMET

\subsection{Germany}

Mackowky and Simonis [6,7] developed by 1969 a calculation based in the Ruhr dilatation test, coal preparation and operating conditions. In their case, the index to express resistance to fissuring was Micum 40 (M40) and abrasion strength Micum 10 (M10), as usual in Europe. Coals and blends of the Ruhr basin were considered [4]. The following expression was used:

$$
M 40=a K+b+M s a(1)
$$

Where $b$ is a function of volatile matter, $M s$ is the sum of positive and negative deviations from optimal grain size es, $\mathrm{K}$ is a function of operating conditions (bulk density, coking rate, oven width), and a $\alpha$ are constants that depend of volatile matter and factor $G$. Factor $G$ is calculated from data of the Ruhr dilatation test: softening temperature (T1), resolidification temperature (T3), \% of maximum contraction (C) and $\%$ of maximum dilatation (D). This factor $\mathrm{G}$ is considered additive for blends.

$$
\text { Factor } \mathrm{G}=\frac{\mathrm{T} 1+\mathrm{T} 3}{2} \times \frac{\mathrm{C}+\mathrm{D}}{\mathrm{DT} 1+\mathrm{CT} 3}
$$

This calculation applies to blends of $18-35 \%$ volatile matter, and an inert content lower than $20 \%$. 


\subsection{Australia}

A model for Australian coals was developed in 1964 by Brown, Taylor and Cook [5]. The calculation takes into account coal rank (reflectance) and petrography. In Australian coals, semifusinite does not behave as partially reactive; so, it is included with the other macerals of the inertinite Group, reporting to the inerts. Besides, most of the inertinite is intimately associated to vitrinite. As a consequence, a dense coke is formed due to the combined action of these two macerals, not as if they were individual components, as in USA coking coals. These coals, according to the Northern hemisphere standards, should not produce a strong coke; nevertheless, they are capable to yield a coke quality adequate for large blast furnaces.

\subsection{South Africa}

Stein and Smith developed a prediction scheme at ISCOR in the late seventies, using petrographic data to calculate M40 and M10 [9]. Many South African coals have low vitrinite and high semifusinite and micrinite. In blends, the values can be somewhat similar, for example $40 \%$ vitrinite and $45 \%$ semifusinite plus micrinite. They could demonstrate that the coke obtained was of superior quality than those produced with coal of high vitrinite. According to their findings, inert and reactive semifusinite are distributed in variable proportions, taking into account two correlations, as function of $\%$ of vitrinite, $\%$ of volatile matter and maximum medium reflectance of vitrinite. Composition Balance Index (CBI) is defined like in the Shapiro - Gray model. Maximum medium reflectance of the reactive macerals (RoR index) is calculated as a function of maximum medium reflectivity of vitrinite, $\%$ vitrinite, $\%$ exinite, \% reactive semifusinite and total\% or reactive macerals. M40 and M10 are determined by using a family of iso-resistance curves, depending on $\mathrm{CBI}$ and RoR index, fig. 4.

This first stage shows the strong influence of the petrographic model by Shapiro and Gray, which is taken as a base by many other researchers. German work adds the effect of operating variables. Reflecting the domestic sourcing of coals, most models of this age deals with the specific features of the coals addressed.

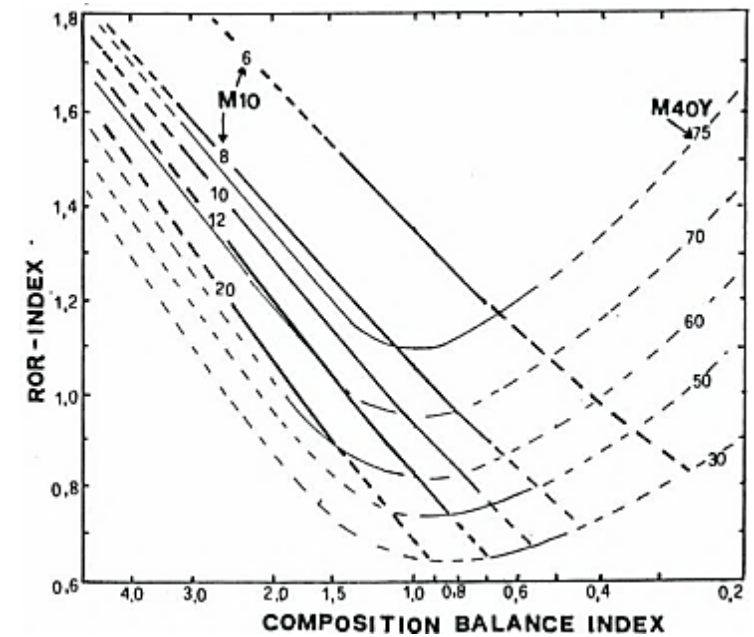

Figure 4. Iso-resistance curves for South African coals [9]. 


\section{SECOND STAGE}

\subsection{Global models - CSR prediction}

In the following period (late seventies, eighties), there was an increase in the international coal trade. New plants were built in Asia and South America, in countries without coal resources. Japan increased its imports from Australia and Canada. European coal mines have started to be close down before, due to a high production cost in comparison with imports. Lower demand by domestic plants in the USA by early eighties prompted exports to Japan and Europe. PCl started to be implemented in blast furnaces, bringing about at the same time less coke consumption but requiring higher quality coke [1].

Under this context, more global coke quality prediction models in Japan and Europe were worked out, including coals from USA, Canada, Australia, South Africa, etc. More coal characterization variables started to be taken into account, rheology in particular. Besides, the interest in coke behavior in the blast furnace arose, claiming for prediction of key coke properties like CSR and CRI.

\subsection{Japan}

One popular model of those times was the so called MOF diagram, owing its name to Miyazu, Okuyama and Fukuyama of the then NKK, including coals form the USA, Australia, Canada and Japan. The criteria is that blends with 1.2 to 1.3 vitrinite and 200 to 1000 ddpm of maximum fluidity, can produce a coke with a cold strength DI $30 / 15>92 \%$ [8], see figure 5 .

Sakawa and others, in Nippon Steel Corporation, worked on modifications of the Shapiro-Gray graph, by 1987. The iso-resistance lines are in terms of $\mathrm{Dl}_{30 / 15}$ and $\mathrm{DI}_{150 / 15}$. Corrections of $\mathrm{CBI}$ and $\mathrm{SI}$, with the maximum fluidity of the blend are made, when Australian and Canadian coals are included [11], see figure 6.

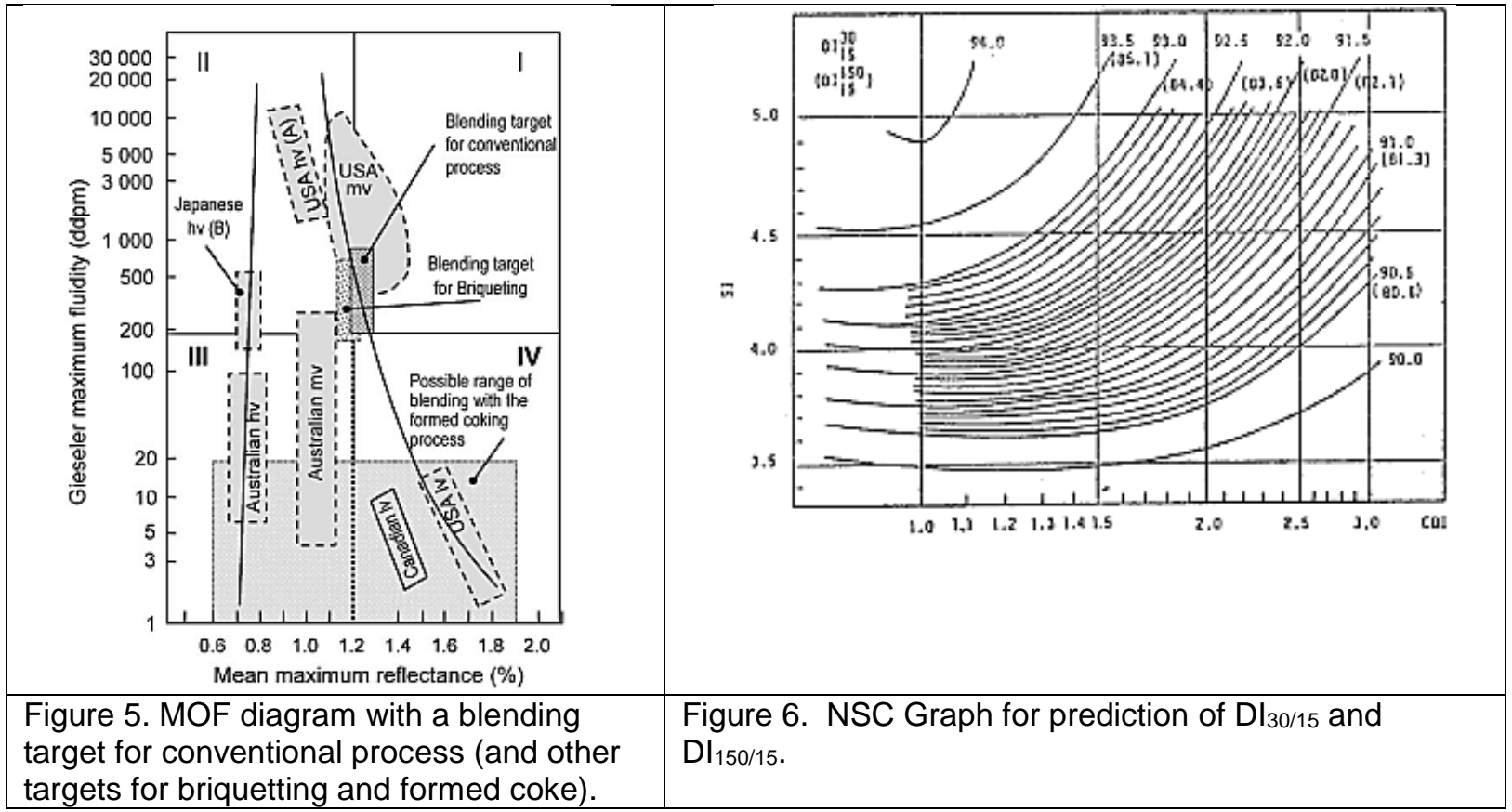




\subsection{Europe}

A highly interesting modeling effort was presented by R. Munnix (CRM) in 1984, using coals from America, Australia, Africa, and Europe. In the base of this concept are the inert content, the so called reactive coking index, and the maximum fluidity [12]. The Total Inert Content (TIC) includes $2 / 3$ semifusinite, inertinite, inert vitrinites (Ro $>1.8)$ and mineral matter. The content of reactives includes reactive vitrinites (Ro < 1.8), exinite and $1 / 3$ of semifusinite. The Reactive Coking Index $(R C l)$ is a function of the reflectance of the vitrinite types contributed by each coal in the blend, called Vitrinite Coking Index, whose value growth from 0.25 to 1 ; Lower values $(0.25$ to 0.4$)$ belong to high-volatile coals, and higher values $(0.8-1)$ to low-volatile coals. Maximum fluidity is incorporated as $\log (m f+1)$, so called LGF, to include inert components in the blend (anthracite, petroleum coke). The output is in terms of cold strength indices M40, M10, 140, I20 and I10. Polynomic third degree functions of TIC, $\mathrm{RCl}$ and LGF are used (Fig. 7).

Another European model of the times was developed at the Coke Research Establishment, UK, by Gibson and Gregory [7-8]. They used as experimental base blends of imported high and low volatile coals. The variables taken into account were the factor $\mathrm{G}$, from the dilatation test; the volatile matter content $(\mathrm{V})$ and the coking time to $900^{\circ} \mathrm{C}(\mathrm{T})$ for a $450 \mathrm{~mm}$ width oven.
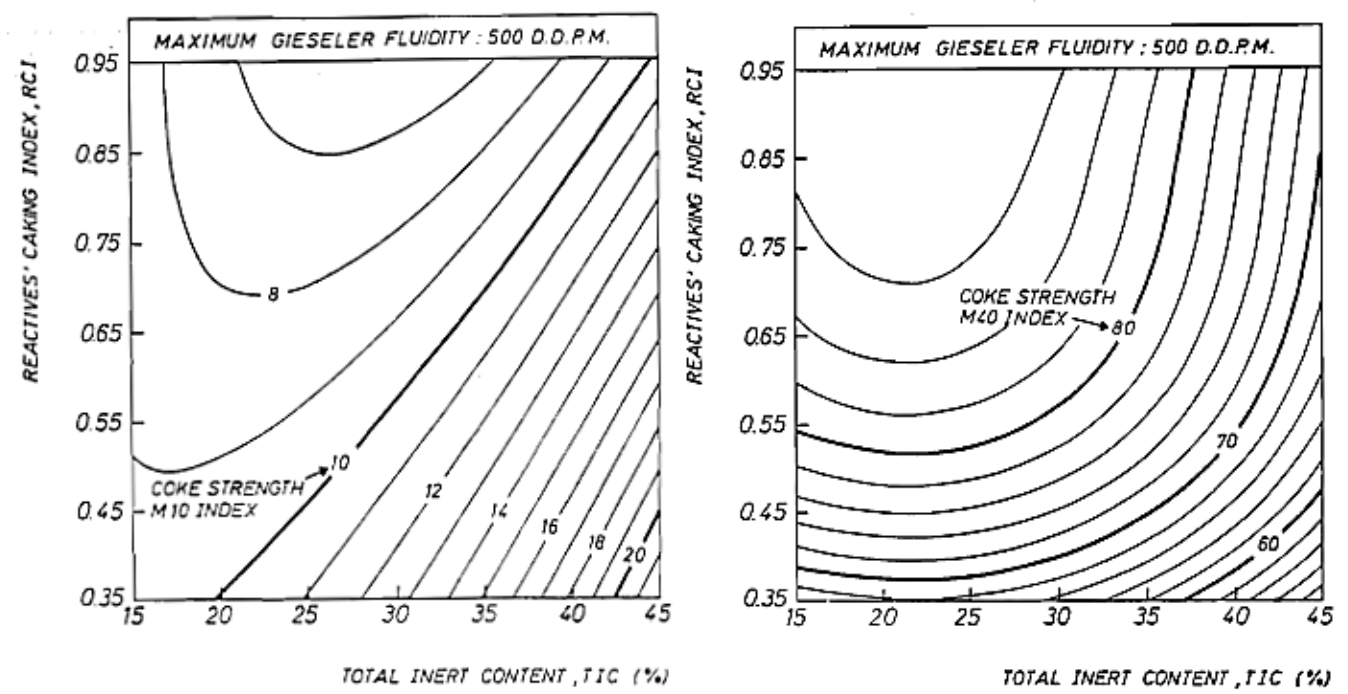

Figure 7. Left: M40 prediction; right: M10 prediction [12].

\subsection{CSR models}

The prediction of the behavior of coke in the blast furnace become more and more important with the dimensional growth of the blast furnaces and the implementation of the pulverized coal injection ( $\mathrm{PCl})$. Just cold strength of coke became not enough. Steel companies and institutes developed prediction models taking into account coal properties. Main variables taken into account in some of these models are presented in table 1. It is clear from table 1 that most of the calculations are based on reflectance and inert content; maximum fluidity and coal ash alkalis. 
Table 1. Models for CSR prediction and variables taken into account.

\begin{tabular}{|c|c|c|c|c|c|c|}
\hline Company & Coal Petrography & $\begin{array}{c}\text { Coal } \\
\text { Rheology }\end{array}$ & Ash & Others & Year & Ref. \\
\hline British Steel & $\begin{array}{l}\text { Vitrinite } \\
\text { reflectance }\end{array}$ & & $\begin{array}{ll}\begin{array}{l}\text { Coke } \\
\text { content }\end{array} & \text { ash } \\
\end{array}$ & & 1977 & 13 \\
\hline NKK & & & & $\begin{array}{l}\text { Coke } \\
\text { petrography }\end{array}$ & 1978 & 13 \\
\hline $\begin{array}{l}\text { Nippon } \\
\text { Steel }\end{array}$ & $\begin{array}{l}\text { Inertinite } \% \text {, } \\
\text { Maximum medium } \\
\text { reflectance }\end{array}$ & $\begin{array}{l}\text { Maximum } \\
\text { fluidity }\end{array}$ & $\begin{array}{l}\text { Coal ash } \\
\text { alkali index }\end{array}$ & & 1980 & 13 \\
\hline BCRA & Inertinite \% & $\begin{array}{l}\text { Maximum } \\
\text { fluidity }\end{array}$ & $\begin{array}{l}\text { Coal alkali } \\
\text { content }\end{array}$ & $\begin{array}{l}\text { Coal Oxygen } \\
\text { and Carbon } \\
\text { content; } \\
\text { pores } / \mathrm{cm}^{2} \text { coke }\end{array}$ & 1982 & 13 \\
\hline Kobe Steel & $\begin{array}{l}\text { Maximum medium } \\
\text { reflectance }\end{array}$ & $\begin{array}{l}\text { Maximum } \\
\text { fluidity }\end{array}$ & $\begin{array}{l}\text { Coal ash } \\
\text { alkali content }\end{array}$ & & 1985 & 13 \\
\hline CANMET & $\begin{array}{l}\text { Maximum medium } \\
\text { reflectance }\end{array}$ & & $\begin{array}{l}\text { Coal ash } \\
\text { modified } \\
\text { basicity index }\end{array}$ & Total dilatation & 1988 & 14 \\
\hline BHP & Inert content & $\begin{array}{l}\text { Maximum } \\
\text { fluidity }\end{array}$ & $\begin{array}{ll}\begin{array}{l}\text { Coal } \\
\text { basicity }\end{array} & \text { ash } \\
\end{array}$ & Volatile matter & 1989 & 14 \\
\hline Inland Steel & & $\begin{array}{l}\text { Plastic } \\
\text { temperature } \\
\text { range }\end{array}$ & $\begin{array}{l}\text { Coal ash } \\
\text { alkali index }\end{array}$ & Coal sulphur & 1989 & 13 \\
\hline ISCOR & $\begin{array}{l}\text { Vitrinites } \\
\text { maximum } \\
\text { reflectance; } \\
\text { organic inerts \% }\end{array}$ & $\begin{array}{l}\text { Maximum } \\
\text { fluidity }\end{array}$ & $\begin{array}{l}\text { Coal ash } \\
\text { basic oxides }\end{array}$ & & 1990 & 8 \\
\hline
\end{tabular}

\section{THIRD STAGE}

\subsection{Updates, neural networks and optimization}

With the new century, coal and iron ore process increased as a consequence of the growing demand, and so did the interest in alternative carbonaceous materials, and process to use some share of weakly coking coals. Models had to be updated, and optimizations tools were developed [17].

\subsection{Some updates to older models}

As mentioned previously, NKK's researchers found in the seventies that the Gieseler Maximum Fluidity (MF) of their coking blends, consisting of many international coals, should be a minimum of $200 \mathrm{ddpm}$ to produce high strength coke. However, coking results with Western Canadian coals alone, or in international blends, showed that high strength coke could be produced at a much lower blend MF. So, a research was carried out recently with different international sources of coal to try to develop a more detailed model to predict the minimum MF required for coke-makers blends. Studies to date on blends of Canadian or USA coals have indicated a lower minimum blend MF required for Canadian coals (20-40 ddpm) and a higher minimum blend MF for USA coals (500-700 ddpm). A suggestion on how to calculate an international coal blend minimum MF is detailed [10]. 


\subsection{Neural network applications}

This technique has been applied to almost all steps in the steel production, including coke plant. In this case, the application has been for a better prediction of CSR. Tata Steel has been active in this field [15]. As an example, in figure 8 is presented the measured values of CSR against the values calculated by using the neural network with back propagation. According to their experience, improvement in the predictions came by increased number of inputs, adopting multilayer hidden strategy and greater number of epochs for training data.

However, since the ANN models have poor interpretability due to the 'black box' structure, it is often merged with the transparent and more interpretable fuzzy logic to form neurofuzzy inference systems. Among the various neurofuzzy models existing in the literature, adaptive neurofuzzy inference system (ANFIS) was selected later on by Tata Steel researchers [16].

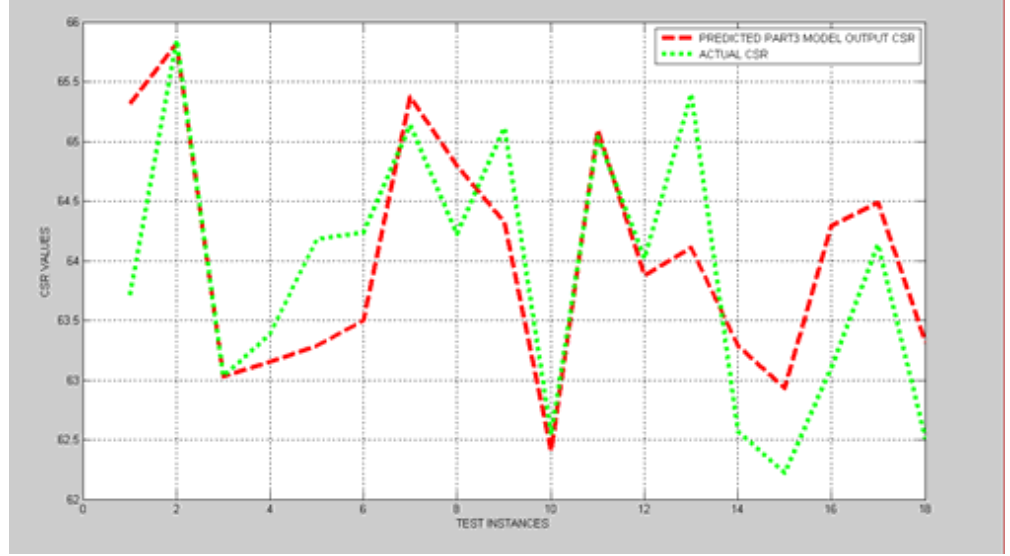

Figure 8. Comparison of CSR measurements and prediction by an artificial neural network based system [15].

\subsection{Optimization models}

\subsubsection{Steel COst OPtimization (SCOOP)}

By the year 2000, experts in operating research at a Belgian university started up a project on an optimization tool for the steel industry. This project was then taken over by N-SIDE. SCCOP is a program that integrates all units of a blast furnace based steel plant, including coke plant, sinter plant, blast furnace and steelmaking, to globally optimize the production process. The aim is to minimize steel production cost by right selection of raw materials and adaptation of the process to market conditions [17]. Some plants using this tool are ArcelorMittal Dunkirk, Erdemir, NLMK, Severstal, CSN, Gerdau Ouro Branco, Usiminas, ThyssenKrupp CSA. For the coal \& coke part, coal properties are the input for the model: ultimate analysis, rheology, reflectance, reactives and inerts content, $\mathrm{CBI}$, SI, etc. When required, lower and upper limits for these properties are defined. Cost and availability of the coals are an input, too. Coal properties are used to predict coke cold strength, as well as CRI and CSR. Then, minimal cost of blend or coke is established, introducing the coal-to-coke yield and operating costs [18].

\subsubsection{Coal Blend Optimization (CBO)}

A well-known producer of coke in heat-recovery horizontal ovens, SunCoke, developed a model for its operations, using MATLAB version 7. A data base with 100 
coals was built, taking into account 58 data per coal: ultimate analysis, chemistry of ash, rheology, petrography, etc. Besides, lower and upper limits to each coal are fixed, as well as the cost. The model read first the coal properties and then the constraints, divided into linear and non-linear, this last linked to various calculation models. As a result, CBO obtains the lowest cost blend of five coals, the blend properties and the forecast of coke properties. It is possible to run the model modifying the constraints [19].

\subsubsection{Coal Blend Optimizer (COBOP)}

ANT Automation, a US-based automation supplier to which one of the authors belong, had built another optimizing model that includes for modules:

- Process model module

- Optimization model module

- Statistical module

- Calibration module

Process model is at the core of the program and has as inputs coal availability, coal properties, and general data. The output includes estimated coal blend properties and coke quality, as well as coke price. The optimization module requires constraints and its output are the least cost blend, expected emissions and coke quality (fig. 9).

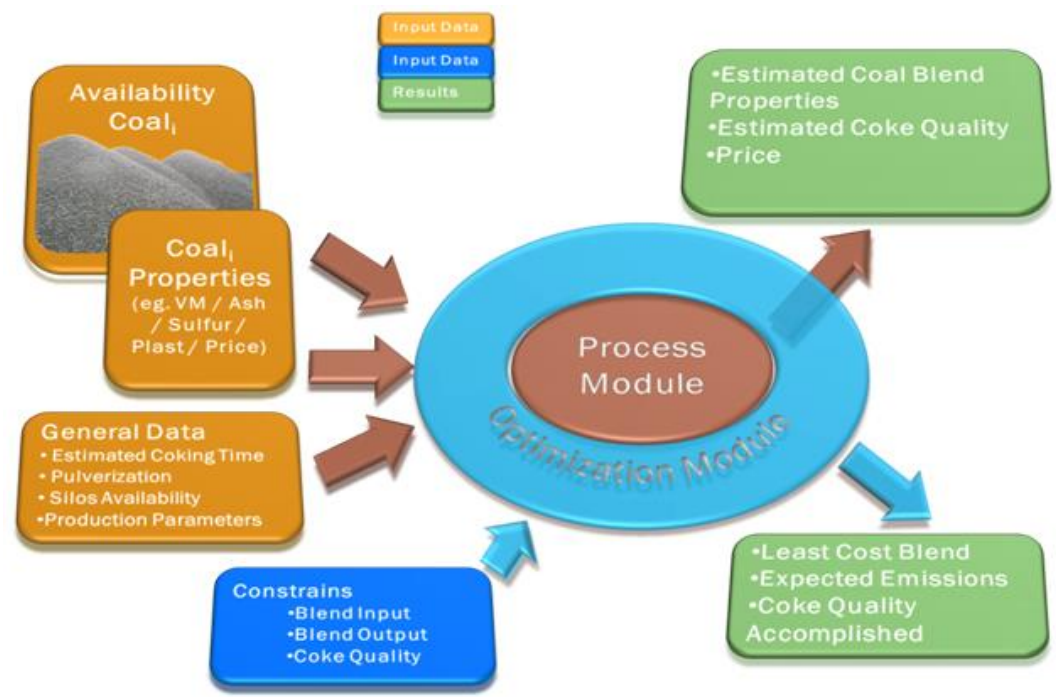

Figure 9. Flow diagram for COBOP program [20].

The object of the model is not only to estimate coal blend and coke properties but also to find a blend that could accomplish with blend / coke quality and production minimizing the coal blend cost to significant levels. It can be considered price coals in the market + the coal price paid taking in account availability on coal yard as well as market opportunities. The main economical savings in the process could be obtained by three main sources: Coal Blend Cost Optimization; Blend Consumption Reduction; These two combined effects.

The software also has a special focus in user experience. It is specially designed to minimize the user input data, and have as much information and data entry as possible in a simple screen. The interface is HTML5 based, what makes it a responsive application that could also run in mobile device. Runs made by different users, can be shared or published among group of selected users inside the same company. Export to MS excel are supported. Other important feature is that it contains a WebApi interface, so data calculated can be consumed by existing 
software platform in the plants, using an open MS-SQL database and WebApi technologies makes it easy to consume and populate data, as well as to build custom reports. The system also can communicates with existing PLCs using the OPC standards, in this way it could be connected to existing automation control for automatic coal blend setup, by downloading the data to PLCs.

The COBOP system enables run comparisons, and trends. By slighting moving parameters in the model, stability chart and any other parameter result can be compared graphically using the user model HTML interface.

\section{CONCLUSIONS}

The models for prediction of coke quality have an intrinsic complexity, as the results are linked to the specific features of the coals, which vary from country to country and within countries. So, the models have been changing along time, as the coal market and the mining and preparation techniques evolved, as well as the coke plant technology and the blast furnace requirements.

Firstly, the Shapiro-Gray's charts combining petrographic variables with coke strength at ambient temperature was taken as a base by many other researchers, modifying the procedure to include features of coals from other countries, and the different cold strength tests (MICUM and IRSID tests in Europe, Dl ${ }_{150 / 30}$ in Japan).

Then, rheology was introduced in different ways, to take into account a direct measurement of coal behavior during coking.

Later on, with the trend to large blast furnaces and $\mathrm{PCI}$, to predict coke behavior at high temperature became imperative and so researchers worked on different ways to get this prediction.

Finally, optimization schemes helped in having a better choice of raw materials, taken into account the complete chain value in some cases, or just coke price and quality in other cases.

\section{REFERENCES}

1 W.R. Leeder, International coking coal market trends, 2002 Ironmaking Conference Proceedings, pp 447-450.

2 M. Elliot, Coke stability from petrographic analysis of coal based on work of Shapiro and Gray), Chemistry of Coal Utilization, Second Supplementary Volume, pp. 146-154.

3 D. Kaegi, Predicting coking stability from coal petrographic analysis, 1981 Ironmaking Conference Proceedings, pp 381-392

4 J. Harrison, H. Jackman, J. Simon, Predicting coke stability from petrographic analysis of Illinois coals. Illinois State Geological Survey, Circular 36, 1964, pp 1-24.

5 R. Gadsden, R. Wilson, Evaluation of Australian coals and cokes for larges blast furnace. 1981 Ironmaking Conference Proceedings, pp 400- 407

6 G. Juranek, Evaluation of coals using the factor " $G$ ". 1979 Ironmaking Conference Proceedings, pp 371-384.

7 W.R. Leeder, J.E. Gransden, J.T. Price, J.C. Botham, Prediction of coke quality with special reference to Canadian coals. Ironmaking Conference Proceedings, Volume 38, 1979, pp 385-397.

8 M.A. Diez, R. Álvarez García, C. Barriocanal, Coal for metallurgical coke predictions of coke quality and future requirements for cokemaking. International Journal of Coal Geology 50 (2002), pp 389-412.

9 P. Jordan, Predicting coke quality based on coal petrography, rheology and coke petrography. Master thesis, University of the Witwatersrand, Johannesburg, South Africa, 2006. 
10 W.R. Leeder, T. Todoschuk, C. Howey, L. Giroux, K.W. Ng, T. MacPhee, Predictive model for blending coking coals to produce high strength coke. METEC \& $2^{\text {nd }}$ ESTAD, Düsseldorf, Germany, June 2015, pp 1-9.

11 M. Sakawa, T. Yamaguchi, Y. Sakurai, T. Okuhara, Selection and evaluation of blends for cokemaking. $1^{\text {st }}$ International Meeting on Coal and Coke Applied to Ironmaking ABM, Rio de Janeiro, Brazil, 1987, pp 169-184.

12 R. Munnix, Compound of coal blends based on a coke strength prediction model. $1^{\text {st }}$ International Meeting on Coal and Coke Applied to Ironmaking - ABM, Rio de Janeiro, Brazil, 1987, pp 209-250.

$13 \mathrm{H}$. Valia, Prediction of coke strength after reaction with $\mathrm{CO}_{2}$ from coal analyses at Inland Steel Company. Transactions of the ISS, May 1989, I\&SM, pp 77 a 87.

14 B.D Ryan, J.T. Price J.T., The predicted coke strength after reaction value of British $L$. coals, with comparisons to international coal. British Columbia Survey, Geological Fieldwork 1992, Paper 1993-1, pp 507-516.

15 S. Maharana, B. Biswas, A. Ganguly, A. Kumar, Artificial neural network prediction for coke strength after reaction and data analysis. International Journal of Chemical, Molecular, Nuclear, Materials and Metallurgical Engineering Vol 4, No. 9, 2010.

A. Suresh, T. Ray, P. S. Dash and P. K. Banerjee, Prediction of coke quality using adaptive neurofuzzy inference system. Ironmaking and Steelmaking 2012 Vol. 39 No. 5 363-369.

16 Haueisen, F. Ferreira, L. Dimas, L. Costa, The benefits of using an optimization tool at Usiminas. $6^{\text {th }}$ International Congress on the Science and Technology of Ironmaking ICSTI, October 2012, Rio de Janeiro, Brazil, pp 2236-2244.

17 http://steel.n-side.com/pdf/benefits.pdf accessed February 2016.

18 J. Perkins, B. Molnar, V. King, J. Quanci, Coal blend optimization for horizontal heat recovery coke plant. $6^{\text {th }}$ International Congress on the Sicience and Technology of Ironmaking - ICSTI, October 2012, Rio de Janeiro, Brazil, pp 2308-2317. http://www.ant-automation.net/cobop accessed February 2016. 